\title{
HUBUNGAN ANTARA NILAI ANKLE BRACHIAL INDEX DENGAN KELEMBABAN KAKI PADA PASIEN DIABETES MELLITUS TIPE II
}

\section{RELATIONSHIP BETWEEN ANKLE BRACHIAL INDEX VALUE AND FOOT MOISTURE IN TYPE II DIABETES MELLITUS PATIENTS}

\author{
Ni Wayan Trisnadewi ${ }^{1}$, Ni Putu Wiwik Oktaviani ${ }^{2}$, I Made Sudarma Adiputra ${ }^{3}$ \\ ${ }^{1}$ Departemen Medikal Bedah, STIKes Wira Medika Bali \\ ${ }^{2}$ Departemen Komunitas dan Keluarga, STIKes Wira Medika Bali \\ ${ }^{3}$ Departemen Komunitas dan Keluarga, STIKes Wira Medika Bali
}

\begin{abstract}
ABSTRAK
Pendahuluan: Diabetes mellitus (DM) merupakan penyakit degeneratif dan kronis, yang memerlukan pengobatan jangka panjang dan perawatan pasien secara mandiri, untuk dapat mencegah efek komplikasi akut maupun komplikasi jangka panjang. Kondisi hiperglikemi berkepanjangan akan menimbulkan komplikasi kronis pada sistem saraf yaitu neuropati diabetic dan juga menurunnya kelembaban kaki. Tujuan penelitian ini untuk mengetahui hubungan antara Nilai Ankle Brachial Index dengan kelembaban dan sensitivitas kaki pasien DM tipe II. Metode: Metode penelitian ini yaitu non-eksperimen studi korelasional, dengan desain penelitian yang digunakan adalah cross sectional, dengan jumlah sampel sebanyak 86 responden diambil dengan tehnik purposive sampling. Pengumpulan data menggunakan tensimeter airaksa, stetoskop dan Skin moisture analyzer. Hasil: Hasil analisa dengan univariat berdasarkan nilai Ankle Brachial Index didapatkan nilai mean 0.99 (Minimum 0.83, Maksimum 1,29) dalam katagori ABI Normal, nilai Kelembaban kaki didapatkan nilai mean 34.11 (Minimum 24.09, Maksimum 47,65) dalam katagori kurang lembab. Hasil Analisa dengan uji Spearman Range didapatkan nilai pvalue 0.000 yang menunjukkan adanya hubungan antara nilai Ankle Brachial Index dengan kelembaban kaki pada pasien DM tipe II. Diskusi: Kesimpulannya berdasarkan hasil penelitian ini dapat disimpulkan bahwa ABI bukan faktor paling dominan mempengaruhi kelembaban kulit kaki pada penderita DM, sehingga diperlukan penelitian lanjutan untuk menemukan factor dominan.
\end{abstract}

Kata kunci: Ankle Brachial Index (ABI), Kelembaban Kulit Kaki, dan Diabetes Melitus

\begin{abstract}
Introduction: Diabetes mellitus (DM) is a degenerative and chronic disease, which requires long-term treatment and independent patient care, to prevent the effects of acute complications and long-term complications. Prolonged hyperglycemic conditions will cause chronic complications to the nervous system, namely diabetic neuropathy and decreased moisture in the feet. The purpose of this study was to determine the relationship
\end{abstract}


between the ankle brachial index value and the humidity and sensitivity of the feet of type II DM patients. Method: This research method is non-experimental correlational study, with the research design used is cross sectional, with a total sample of 86 respondents taken by purposive sampling technique. Data collection used a mercury tensimeter, stethoscope and skin moisture analyzer. Results: The results of univariate analysis based on the Ankle Brachial Index value obtained a mean value of 0.99 (Minimum 0.83, Maximum 1.29) in the Normal ABI category, the moisture value of the feet obtained a mean value of 34.11 (Minimum 24.09, Maximum 47.65) in the less moisture category. The results of the analysis with the Spearman Range test obtained a p-value of 0.000 which indicates a relationship between the value of the Ankle Brachial Index and the moisture of the feet in type II DM patients. Discussion: The conclusion based on the results of this study it can be concluded that $\mathrm{ABI}$ is not the most dominant factor affecting the moisture of the foot skin in DM patients, so further research is needed to find the dominant factor.

Keywords: Ankle Brachial Index (ABI), Foot Skin Moisture, and Diabetes Mellitus

\begin{tabular}{ll}
\hline Alamat Korespondensi & : Departemen Medikal Bedah, STIKes Wira Medika Bali \\
Email & : trisnawika09@gmail.com \\
\hline
\end{tabular}

\section{PENDAHULUAN}

Diabetes mellitus (DM) merupakan penyakit degeneratif dan kronis, yang memerlukan pengobatan jangka panjang dan perawatan pasien secara mandiri, untuk dapat mencegah efek komplikasi akut maupun komplikasi jangka panjang. Menurut Internasional of Diabetic Federation (2015) kejadian penyakit Diabetes mellitus dengan tingkat prevalensi global pada tahun 2014 sebesar 8,3\% dari keseluruhan penduduk di dunia dan mengalami peningkatan pada tahun 2014 menjadi 387 juta kasus (IDF, 2015). Indonesia merupakan negara yang menempati urutan ke 7 dengan penderita DM sejumlah 8,5 juta penderita setelah Cina, India dan Amerika Serikat, Brazil, Rusia, Mexico dan saat ini telah bergeser menduduki urutan ke 5 tertinggi di dunia dengan angka kejadian 9.1 juta orang menurut perkumpulan endokrinologi (PERKENI, 2015). WHO memprediksi kenaikan jumlah penyandang DM di Indonesia dari 8.4 juta pada tahun 2000 menjadi sekitar 21.3 juta pada tahun 2030. Laporan ini menunjukkan adanya peningkatan jumlah penyandang DM sebanyak 2-3 kali lipat pada tahun 2035 (PERKENI, 2015).

Komplikasi pada penderita DM, terutama pada penderita dewasa dan lanjut usia, biasanya terjadi karena gula darah yang tidak terkontrol dalam waktu yang lama dan karena adanya penurunan daya tahan tubuh. Penderita DM lanjut dapat mengakibatkan gangguan metabolik akut (ketoasidosis), komplikasi vaskuler jangka panjang (retinopati dibetik), mikroangiopaty, makroangiopaty dan gangrene (Smeltzer \& Bare, 2013). Individu dengan diabetes memiliki risiko tinggi untuk mengalami kecacatan dan ancaman masalah kesehatan dibandingkan idividu tanpa DM. Kadar glukosa yang tinggi secara terus menerus akan mengakibatkan penyakit serius yang mempengaruhi jantung, pembuluh darah, mata, ginjal dan saraf. Individu dengan diabetes juga akan memiliki risiko tinggi untuk mengalami infeksi (ADA, 2017). 
Disamping itu, kondisi hiperglikemi berkepanjangan juga akan menimbulkan komplikasi kronis lainnya pada system saraf yaitu neuropati diabetic. Neuropati diabetic ini akan menyerang sistem saraf sensorik dan otonom. Adapaun manifestasi neuropati pada system saraf sensorik dan otonom adalah neuropati sudomotorik yang mengarah kepada penurunan atau ketiadaan keringat (anhidrosis) pada ekstremitas. Hal ini akan menyebabkan terjadinya penurunan kelembaban kulit sehingga kulit akan menjadi kering (Smeltzer \& Bare, 2013). Berdasarkan penelitian yang dilakukan oleh Purwanti (2013) menunjukkan bahwa 76.5\% pasien dengan ulkus mengalami neuropati otonom dan $23.5 \%$ tidak mengalami neuropati otonom. Selain itu juga akan terjadi iskemia pada system saraf kaki. Iskemia system saraf dapat mengakibatkan transmisi impuls saraf yang terganggu sehingga akan merusak system saraf (Bilous \& Donelly, 2014). Kerusakan system saraf didukung oleh kelebihan glukosa pada jaringan saraf. Akibat kelebihan glukosa akan merubah aktivitas berbagai jalur biokimia, seperti terjadinya sintesis Advance Glycosilation End Products (AGEs), pembentukan radikal bebas dan aktivasi protein kinase $\mathrm{C}$ (PKC). Aktivasi berbagai jalur biokimia tersebut berujung pada kurangnya vasodilatasi pembuluh darah, yang menyebabkan aliran darah ke saraf menurun. Hal tersebut akan mengganggu metabolism sel Schwann sehingga menyebabkan terjadinya penurunan sensitifitas kaki penderita DM (Soegondo, 2011).

Beberapa hasil penelitian menunjukkan bahwa kejadian neuropati pada pasien DM sangat tinggi. Penelitian yang dilakukan di Saudi Arabia menunjukkan bahwa manifestasi kulit pada kasus diabetes mellitus sebanyak 74,7\% dari 558 orang mengalami kulit kering atau mengalami penurunan kelembaban kulit (Samer, 2012). Penelitian yang dilakukan oleh Duff, Demidova, Blackburn, dan Shubrook (2015) menunjukkan dari 750 orang dengan diabetes, sebanyak 26,4\% responden mengalami kulit kering. Terjadinya penurunan kelembaban kulit pada kaki serta kehilangan sensitivitas kaki dapat menyebabkan risiko cedera dan timbulnya ulkus kaki yang berujung pada diabetic foot (Smeltzer \& Bare, 2013).

Salah satu upaya untuk mengetahui keadekuatan sirkulasi vaskuler perifer ke daerah tungkai pada penderita DM adalah dengan membandingkan nilai tekanan darah sistolik tertinggi ekstremitas bawah dan atas, upaya ini dikenal dengan pemeriksaan Ankle brachial index (ABI). Hasil pengukuran ABI merupakan tanda keadaan sirkulasi darah pada tungkai bawah dengan rentang nilai sama atau lebih dari 0.90 menunjukkan bahwa sirkulasi darah ke daerah tungkai normal dan apabila kurang dari 0,90 menunjukkan sirkulasi ke daerah kaki mengalami obstruksi (Wahyuni \& Arisfa, 2016). Nilai ABI memiliki spesifisitas 83,33-99,0\% dan akurasi yang tinggi (72,1-89,2\%) menunjukkan bahwa seorang pasien memungkinkan telah mengalami stenosis $\geq 50 \%$ bila didapatkan nilai $\mathrm{ABI} \leq 90 \%$ (Xu, Pan, \& Liu, 2010).

Berdasarkan studi pendahuluan yang dilakukan di Puskesmas I Denpasar Selatan, didapatkan jumlah kunjungan untuk pasien DM tipe II selama 3 bulan sejak nulan April sampai Juni sebanyak 110 kunjungan pasien DM tipe 2. Hasil pengukuran ABI yang dilakukan pada 10 orang penderita DM tipe II yang diukur pada saat mengikuti kegiatan Prolanis didapatkan 6 dari 10 penderita memiliki nilai ABI di bawah 0.91. penelitian ini bertujuan untuk mengetahui hubungan antara nilai ankle brachial index dengan kelembaban kaki pada pasien diabetes mellitus tipe II. 
Penelitian ini bermanfaat untuk membantu pasien mencegah komplikasi pada pada pasien DM tipe 2 khususnya kejadian kaki diabetik.

\section{METODE PENELITIAN}

Dalam penelitian ini peneliti menggunakan rancangan non-eksperimen studi korelasional. Penelitian ini menggunakan metode pendekatan cross-sectional yang menekankan waktu pengukuran variabel independen dan dependen hanya satu kali pada satu saat (Nursalam, 2013). Penelitian ini dilaksanakan di Puskesmas I Denpasar Selatan pada bulan November 2019. Besar sampel dalam penelitian ini berjumlah 86 responden. Sampel dalam penelitian diambil menggunakan teknik non probability sampling yaitu purposive sampling. Variabel bebas dalam penelitian ini adalah Nilai Ankle Brachial Index dan variabel terikatnya adalah Kelembaban Kaki pada pasien DM tipe 2. Penelitian ini menggunakan alat ukur tensimeter airaksa, stetoskop dan Skin moisture analyzer. Dalam penelitian ini data dianalisis univariat dan bivariat. Secara univariat data dianalisis dengan menggunakan statistik deskriptif, kemudian hasilnya disajikan dalam bentuk narasi dan tabel distribusi frekuensi. Uji bivariat yang digunakan dalam penelitian ini adalah uji Spearman Range untuk mengetahui hubungan antara Nilai Ankle Brachial Index dengan klembaban kaki pada pasien diabetes melitus tipe II di Puskesmas I Denpasar Selatan dengan ketentuan jika nilai $\mathrm{p}<0.05$ maka dapat disimpulkan bahwa terdapat korelasi yang signifikan antara variabel yang dihubungkan begitu juga sebaliknya.

\section{HASIL DAN PEMBAHASAN}

\section{HASIL PENELITIAN}

\section{Karakteristik Responden Berdasarkan Jenis Kelamin}

Tabel 1

Distribusi Frekuensi Karakteristik Responden Berdasarkan Jenis Kelamin

\begin{tabular}{ccc}
\hline Kelompok & Frekuensi & Presentase (\%) \\
\hline Laki-laki & 41 & 47.7 \\
\hline Perempuan & 45 & 52.3 \\
\hline Total & 86 & 100 \\
\hline
\end{tabular}

Berdasarkan tabel 1 diketahui distribusi frekuensi responden terbanyak adalah berjenis kelamin perempuan (52.3\%).

\section{Karakteristik responden berdasarkan umur dan lama menderita DM}

Tabel 2

Distribusi Frekuensi Karakteristik Responden Berdasarkan umur dan lama menderita DM

\begin{tabular}{lccc}
\hline \multicolumn{1}{c}{ Kelompok } & Minimum & Maximum & Mean \\
\hline Umur & 47 & 67 & 55.28 \\
\hline Lama Menderita DM & 3 & 13 & 2.372 \\
\hline
\end{tabular}


Berdasarkan tabel 2 diketahui nilai mean untuk umur responden adalah 55.28 dan nilai mean untuk lama menderita DM adalah 2.372.

\section{Hasil Penelitian Berdasarkan Variabel Penelitian}

Tabel 3

Distribusi Ankle Brachial Index (ABI) \& Kelembaban Kaki

\begin{tabular}{lccc}
\hline \multicolumn{1}{c}{ Kelompok } & Minimum & Maximum & Mean \\
\hline Ankle Brachial Index (ABI) & 0.83 & 1.29 & 0.99 \\
\hline Kelembaban Kaki & 24.09 & 47.65 & 34.11 \\
\hline
\end{tabular}

Berdasarkan tabel 3 dapat dilihat bahwa nilai mean untuk Ankle Brachial Index adalah 0.99, nilai mean untuk kelembaban kaki adalah 34.11.

\section{Hasil analisis Hubungan Variabel Independent dan Variabel Dependent}

Tabel 4

Hasil Analisa Hubungan Variabel Independent dan Variabel Dependent

\begin{tabular}{ccc}
\hline Variabel & Jumlah Sampel & P Value \\
\hline ABI dengan & 86 & 0.000 \\
Kelembaban Kaki & & \\
\hline
\end{tabular}

Berdasarkan tabel 4 dapat dilihat bahwa hasil analisisi antara ABI dengan kelembaban kaki dengan nilai P value 0.000 .

\section{Diskusi}

Hasil Analisa data berdasarkan umur didapatkan nilai mean untuk usia pasien adalah 55.28 dengan nilai minimum 47 tahun dan maksimum 67 tahun. Menurut Smeltzer, Bare, Hinkle, dan Cheever (2010) DM banyak dialami oleh usia di atas 40 tahun, karena resistensi insulin pada penderita DM meningkat pada usia 40 - 60 tahun. Penelitian yang dilakukan oleh Trisnawati dan Setyorogo (2013), peningkatan risiko terjadi DM paling rentan terjadi pada kelompok umur 45 tahun ke atas karena faktor degeneratif di mana fungsi tubuh untuk metabolisme glukosa mulai menurun sehingga terjadi peningkatan intoleransi glukosa. Berdasarkan hasil Analisa data didapatkan jenis kelamin pasien sebagian besar perempuan yaitu sebanyak $52.3 \%$. Hal ini serupa dengan hasil penelitian yang dilakukan oleh Kistianita, Yunus, dan Gayatri (2018) yang menunjukan pasien yang mengalami diabetes melitus tipe 2 berjenis kelamin perempuan lebih banyak $(55,3 \%)$ dari pada laki-laki (44,7\%). Perempuan lebih berisiko mengidap diabetes karena sindroma siklus bulanan, pasca menopause yang membuat distribusi lemak tubuh menjadi mudah terakumulasi akibat proses hormonal tersebut sehingga perempuan berisiko mengidap diabetes melitus tipe 2 (Irawan, 2010). Guyton dan Hall (2007) juga memaparkan bahwa perempuan lebih beresiko menderita penyakit DM tipe 2 dikarenakan pada wanita secara alami akan mengalami masa menopause sehingga terjadi penurunan produksi hormon esterogen dan progesterone. Penurunan hormone tersebut menyebabkan terjadinya perubahan komposisi lemak yang memicu metabolisme karbohidrat dan lipid menjadi abnormal. Hal ini mengakibatkan terjadinya deposisi lemak subkutan menjadi lemak abdominal dan viseral yang menyebabkan peningkatan insiden sindrom metabolik. Akibat proses hormonal tersebut membuat perempuan berisiko 55 menderita diabetes mellitus. 
Hal ini juga sejalan dengan teori Smeltzer et al. (2010) yang menyatakan bahwa perempuan lebih berisiko terkena diabetes melitus dari pada laki-laki. Sehingga peneliti berasumsi jenis kelamin merupakan salah satu factor penyebab terjadinya DM dan neuropati diabetic.

Berdasarkan lama menderita DM dalam tahun didapatkan nilai mean 2.372 dengan nilai minimum 3 tahun dan nilai maksimum adalah 13 tahun. Penelitian ini sejalan dengan penelitian yang dilakukan oleh Restada (2016) yang menemukan mayoritas responden DM telah menderita DM sejak 6- 10 tahun yaitu sebanyak 32 orang (36\%). Lamanya menderita diabetes melitus menyebabkan risiko timbulnya komplikasi. Komplikasi diabetes biasanya terjadi pada pasien yang menderita diabetes melitus rata-rata selama 5 - 10 tahun dengan kadar gula darah yang tidak terkontrol yaitu dimana kadar gula darah sewaktu $\geq 200 \mathrm{mg} / \mathrm{dL}$ dan kadar gula darah puasa $\geq 126 \mathrm{mg} / \mathrm{dL}$ (Enthusiast, 2012). Peneliti berasumsi bahwa banyak responden diabetes melitus yang baru terdiagnosa pada saat telah mengalami komplikasi yang dirasakan cukup berat padahal proses penyakit telah berlangsung bertahun-tahun sebelumnya namun belum terdiagnosis.

Hasil Analisa data nilai ABI pada pasien DM dalam penelitian ini yaitu dengan nilai mean 0.99 dengan nilai minimum 0.83 dan nilai maksimum 1.29. Menurut ADA (2017) nilai ABI normal berkisar 0,91-1,30. Hasil penelitian ini sesuai dengan penelitian sebelumnya yang dilakukan oleh Priyanka \& Hardy (2013) di Poliklinik Penyakit Dalam RSUD Sanjiwani Gianyar yang menemukan sebanyak $52,9 \%$ pada kelompok perlakuan dan sebanyak $64,7 \%$ pada kelompok control pasien DM tipe 2 yang mengalami nilai ABI normal $(0,91-1,3)$. Penelitian yang dilakukan oleh Safitri (2017) didapatkan mayoritas penderita DM di Persadia Cabang Surakarta yaitu dalam rentang normal dan disusul dengan nilai ABI ringan. Temuan yang sama juga disampaikan dalam penelitian yang dilakukan oleh Sukarja, Sukawana, dan Wedri (2016) yang menemukakan bahwa semua diabetesi di wilayah kerja Puskesmas Ubud I memiliki nilai ABI normal.

Hasil pengamatan terhadap 86 responden didapatkan nilai kelembaban kaki pasien DM tipe II di Puskesmas I Denpasar Selatan didapatkan nilai mean 34.11 dengan nilai minimum 24.09 dan nilai maksimum 47.65. Berdasarkan hasil penelitian ini secara umum dapat diketahui bahwa pasien DM di Puskesmas Denpasar Selatan 2019 mayoritas mengalami kulit kering. Hal ini sesuai dengan kategori nilai kelembaban yang diungkapkan Pray dan Pray (2006) yaitu nilai normal kelembaban kulit 45\%- 65\%, kering 65\%. Hasil penelitian ini sesuai dngan penelitian sebelumya yang dilakukan oleh Wih et al. (2009) yaitu didapatkan nilai rata-rata kelembaban kulit kaki sebesar 30,8\% pada kelompok perlakuan dan 32,9\% pada kelompok control. Hasil ini tidak jauh berbeda dengan penelitian Cahyani dalam Chomariyah (2016) bahwa rata-rata kelembaban kulit kaki yang diukur dengan skin moisture pada penelitian tersebut adalah 31,44\% yang berarti pasien sudah mengalami penurunan kelembaban kulit kaki yang mempunyai kisaran normal yaitu $45-65 \%$. Hal yang sama juga disebutkan dalam penelitian yang dilakukan oleh Sukarja, Sukawana, dan Wedri (2016) di wilayah kerja Puskesmas Ubud I yang menemukakan bahwa seluruh (100\%) diabetesi mengalami kulit kering. Hal ini juga didukung oleh teori dari Smeltzer et al. (2010) mengenai hiperglikemia berkepanjangan yang menimbulkan komplikasi kronis pada sistem saraf sehingga terjadi neuropati diabetik. Neuropati diabetik dapat mengenai sistem 
saraf sensorik dan otonom. Salah satu manifestasi neuropati pada sistem saraf otonom adalah neuropati sudomotorik yang mengacu pada penurunan atau ketiadaan keringat (anhidrosis) pada ekstremitas. Hal ini menyebabkan penurunan kelembaban kaki dan kaki kehilangan kemampuan alami untuk melembabkan kulit sehingga kulit menjadi kering. Penurunan kelembaban kulit atau kering pada umumnya terjadi pada lansia, yaitu pada usia 65 tahun keatas karena perubahan fisiologis yang terjadi. Penurunan kelembaban kulit pada lansia disebabkan oleh penipisan epidermis (Bianti, 2016). Perempuan yang mengalami menopause terjadi ketidakseimbangan hormone yang berpengaruh terhadap penurunan aktivasi kelenjar sebasea pada kulit yang menyebabkan penurunan jumlah dan ukuran sebasea. Selain itu estrogen juga menurunkan produksi dari sebum. Hal ini menyebakan kulit kehilangan kemampuan untuk melembabkan secara alami (Elis, Sawitri, Fauzi, \& Widyani, 2009). Lama menderita diabetes melitus dapat menyebabkan terjadinya komplikasi. Penyebab yang spesifik dan patogenesis setiap jenis komplikasi masih terus diselidiki, namun peningkatan kadar glukosa darah tampaknya berperan dalam proses terjadinya kelainan neuropatik, komplikasi mikrovaskuler dan sebagai faktor resiko timbulnya komplikasi mikovaskuler (Smeltzer \& Bare, 2013).

Hasil Analisa hubungan antara ABI kelembaban kaki didapatkan hasil $p$ value 0.000. Hasil penelitian yang dilakukan oleh Rahmaningsih (2016) menemukan bahwa 2 hal utama yang mengawali ulkus diabetikum adalah menurunnya perfusi dari arterial ke ekstremitas bawah dan neuropati. Penelitian oleh Wijaya dan Putri (2013) menyatakan bahwa semakin buruk nilai ABI akan semakin berat kerusakan yang terjadi pada saraf maupun pembuluh darah. Hal serupa disampaikan oleh Suyanto (2017) dalam penelitiannya yaitu salah satu faktor penting yang menyebabkan masalah pada pasien DM seperti makrovaskular dan mikrovaskuler adalah gangguan pada pembuluh darah. Penelitian ini sejalan dengan teori yang disampaikan oleh Waspadji, Sukardji, dan Suharyati (2015) mengenai hiperglikemia berkepanjangan yang menyebabkan perubahan di beberapa jalur biokimia yang berdampak pada sel, salah satunya yaitu jalur protein kinase $\mathrm{C}$ menyebabkan penebalan dinding pembuluh darah yang mengakibatkan penurunan aliran darah. Penurunan suplai darah ke kaki mengakibatkan tekanan darah sistolik pada kaki lebih rendah dibandingkan dengan tekanan darah sistolik pada daerah brachial. Perbandingan tekanan darah sistolik ekstremitas bawah dan atas disebut dengan Ankle Brachial Index (Wocn, 2012). Penurunan nilai ABI menunjukan penurunan sirkulasi darah ke jaringan. Penurunan aliran darah ke sistem saraf menyebabkan terjadinya iskemia pada sistem saraf. Hal ini mengakibatkan perubahan biokimia sel saraf dan mengganggu kegiatan metabolik sel schwan sehingga terjadi neuropati diabetik (ND) (Subekti, 2015). Neuropati diabetik dapat mengenai sistem saraf sensorik dan otonom. Salah satu manifestasi neuropati pada sistem saraf otonom adalah neuropati sudomotorik. Neuropati sudomotorik menyebabkan berkurangnya keringat, minyak kelenjar fungsionalis, hal ini disebabkan berkurangnya pengeluaran keringat (ekrin) dimana kecepatan sekresi keringat dikendalikan saraf simpatis. Kelenjar keringat terdapat pada sebagian besar permukaan tubuh terutama pada telapak tangan dan kaki (Corwin, 2009). Akibat dari berkurangnya pengeluaran keringat, kulit kaki kehilangan 
kemampuan alami untuk melembabkan kulit sehingga kulit menjadi kering (Smeltzer \& Bare, 2013).

\section{SIMPULAN DAN SARAN}

Berdasarkan hasil penelitian tentang "Hubungan antara Nilai Ankle Brachial Index dengan Kelembaban Kaki pada pasien DM tipe II di Puskesmas I Denpasar Selatan" dan pembahasan dapat ditarik kesimpulan bahwa ABI mempengaruhi kelembaban kulit kaki pada penderita DM, diperlukan penelitian lanjutan untuk menemukan faktor-faktor dominan yang mempengaruhi kelembaban pada kaki pasien DM tipe 2. Diharapkan hasil penelitian ini dapat digunakan sebagai acuan dalam pengembangan penelitian lebih lanjut tentang pemeriksaan ABI dan kelembaban kaki pada pasien DM tipe 2.

\section{DAFTAR PUSTAKA}

ADA. (2017). Diabetes Care; Standar Of Diabetes Care In Diabetes (M. et al William T. Cefalu, ed.). https://doi.org/DOI: 10.2337/dc17-S001

Bianti, M. (2016). Kulit Kering pada Usia Lanjut. Continuing Medical Education 245, 43(10), 737-740.

Bilous, R. \& Donelly, R. (2014). Buku Pegangan Diabetes Edisi Ke 4. Jakarta: Bumi Medika.

Chomariyah, N. (2016). Optimasi Sediaan Pelembab Ekstrak Kering Kulit Buah Manggis (Garcinia mangostana L.) dengan Kombinasi Asam Stearat dan Trietanolamin sebagai Emulgator. Widya Mandala Catholic University Surabaya.

Corwin, E. . (2009). Buku Saku Patofisiologi. Edisi Revisi 3. Jakarta: EGC.

Duff, M., Demidova, O., Blackburn, S., \& Shubrook, J. (2015). Cutaneous Manifestations of Diabetes Mellitus. Clinical Diabetes, 33(1), 40-48.

Elis, I., Sawitri, I., Fauzi, N., \& Widyani, R. (2009). Kulit dan Menopause Manifestasi dan Penatalaksanaan (Skin and Menopause - Manifestation and Treatment). Berkala Ilmu Kesehatan Kulit \& Kelamin, 48-55.

Enthusiast, B. H. (2012). Diabetic Foot Ulcer. Available at: www.healthyentusiast.com/diabetic-foot-ulcer.html (Diakses 20 Februari 2018).

Guyton, A. C., \& Hall, J. E. (2007). Buku Ajar Fisiologi Kedokteran : Hipertensi Primer. Jakarta: EGC.

IDF. (2015). IDF Diabetes Atlas 2015 (S. W. David Cavan, Joao da Rocha Fernandes, Lydia Makaroff, Katherine Ogurtsova, Ed.). International Diabetes Federation.

Irawan. (2010). Prevalensi dan Faktor Risiko Kejadian Diabetes Melitus Tipe 2 Di Daerah Urban Indonesia Analisa Data Sekunder Riskesdas 2007. Jakarta.

Kistianita, A. N., Yunus, M., \& Gayatri, R. W. (2018). Analisis Faktor Risiko DIabetes Mellitus Tipe 2 pada Usia Produktif dengan Pendekatan WHO Stepwise Step 1 (Core/Inti) di Puskesmas Kendalkerep Kota Malang. Preventia: The Indonesian Journal of Public Health, 3(1).

Nursalam. (2013). Metode Penelitian Ilmu Keperawatan. Jakarta: Salemba Medika. 
PERKENI. (2015). Konsensus: Pengelolaan dan Pencegahan Diabetes Mellitus Tipe 2 di Indonesia (PB PERKENI, Ed.).

Pray, W., \& Pray, J. (2006). Managing Dry Skin. US: Pharmacist.

Priyanka, I. W. A., \& Hardy, I. (2013). Pengaruh Bauran Pemasaran Terhadap Jumlah Kunjungan Pasien di Poliklinik Raat Jalan Rumah Sakit Umum Daerah Sanjiwani Gianyar. Community Health, 1(2), 99-111.

Purwanti, O. S. (2013). Hubungan Faktor Risiko Neuropati dengan Kejadian Ulkus Kaki pada Pasien Diabetes Mellitus di RSUD Moewardi Surakarta. Prosiding Seminar Ilmiah Nasional Kesehatan 2013. Diambil dari https://publikasiilmiah.ums.ac.id/handle/11617/3403

Rahmaningsih, S. (2016). Hubungan Dukungan Keluarga Dengan Kepatuhan Pasien Dalam Pengaturan Jadwal Makan Pada Pasien Diabetes Melitus Tipe 2 Di Rumah Sakit Dr.Soepraoen Malang. Universitas Brawijaya.

Restada, E. J. (2016). Hubungan Lama Menderita dan Komplikasi Diabetes Melitus dengan Kualitas Hidup pada Pasien Penderita Diabetes Melitus di WIlayah Puskesmas Gatak Sukoharjo. Universitas Muhammadiyah Surakarta.

Safitri, L. (2017). Hubungan Nilai Ankle Brachial Index (Abi) Dengan Kualitas Hidup Penderita Diabetes Melitus Tipe 2 Di Persadia Cabang Kota Surakarta. Universitas Muhammadiyah Surakarta.

Samer, K. . (2012). Prevalence of Skin Manifestations in Diabetes Mellitus at King Abdulaziz University Hospital. Saudi Journal of Internal Medicine, 2(1), 1922.

Smeltzer, S. C., \& Bare, B. G. (2013). Buku Ajar Keperawatan Medikal Bedah Brunner \& Suddarth, edisi 8. Jakarta: EGC.

Smeltzer, S. C., Bare, B. G., Hinkle, J. L., \& Cheever, K. H. (2010). Brunner AndSuddarth's Text Book Of Medical Surgical Nursing (11 ed.). Philadepia: Lippincott Williams \& Wilkins, Inc.

Soegondo, S. (2011). Diagnosis dan Klasifikasi Diabetes Melitus Terkini dalam: Soegondo, S., Soewondo, P., Subekti, I., Editor. Penatalaksanaan Diabetes Melitus Terpadu bagi dokter maupun edukator diabetes. Jakarta: Fakultas Kedokteran Universitas Indonesia.

Subekti. (2015). Neuropati Diabetik. Jakarta: Interna Publishing.

Sukarja, I., Sukawana, I., \& Wedri, N. (2016). Senam Kaki dan Stimulasi Kutaneus terhadap Kelembaban Kulit Kaki pada Diabetesi. Jurnal Gema Keperawatan, 9(2), 214-220.

Suyanto. (2017). Gambaran Karakteristik Penderita Neuropati Perifer Diabetik. Nurscope: Jurnal Penelitian dan Pemikiran Ilmiah Keperawatan, 3(1), 1-6.

Trisnawati, S. K., \& Setyorogo, S. (2013). Faktor ResikoKejadian Diabetes Melitus tipe II di Puskesmas Kecamatan Cengkareng Jakarta Barat Tahun 2012. Jurnal Ilmiah Kesehatan, 5(1).

Wahyuni, A., \& Arisfa, N. (2016). Senam Kaki Diabetik Efektif Meningkatkan Ankle Brachial Index Pasien Diabetes Melitus Tipe 2. Jurnal Ipteks Terapan, 2, 155-164.

Waspadji, S., Sukardji, K., \& Suharyati. (2015). Menyusun Diet Berbagai Penyakit Berdasarkan Daftar Bahan Makanan Penukar. Jakarta: Fakultas Kedokteran Universitas Indonesia.

Wih, W. L., Ranti, A. S., Wasitaatmadja, S. M., Suryaningsih, Junardy, F. D., \& 
Bali Medika Jurnal.

Vol 8 No 1, 2021: 72-81

ISSN : 2615-7047

DOI: https://doi.org/10.36376/bmj.v8i1

Maily. (2009). Penelitian Bahan Pencerah dan Pelembab Kulit dari Tanaman Indonesia. Majalah Ilmu Kefarmasian, 6(1), 01-08.

Wijaya, A. S., \& Putri, Y. M. (2013). KMB 2 Keperawatan Medikal Bedah: Keperawatan Dewasa Teori dan Contoh Askep. Yogyakarta: Nuha Medika.

Wocn, J. (2012). Ankle Brachial Index. Journal of Wound, Ostomy and Continence Nursing, 39(April), S21-S29.

Xu, Y., Pan, W., \& Liu, H. (2010). Self-management practices of Chinese Americans with type 2 diabetes. Nursing and Health Sciences, 12, 228-234. https://doi.org/doi: 10.1111/j.1442-2018.2010.00524.x. 